\title{
Renal Manifestations among Adult Sickle Cell Disease Patients: A Single Center Study in Khartoum, Sudan
}

\author{
Amin S. Banaga1, Hala I. Elhardlu², Khalifa Elmusharaf ${ }^{3}$ \\ ${ }^{1}$ Department of Medicine \& Nephrology, University of Medical Sciences and Technology, Academy Charity Teaching Hospital, \\ Khartoum, Sudan \\ ${ }^{2}$ Clinical Research Assistants, Department of Nephrology, Academy Charity Teaching Hospital, Khartoum, Sudan \\ ${ }^{3}$ Graduate Entry Medical School, University of Limerick, Ireland \\ Email: amin.banaga@gmail.com
}

How to cite this paper: Banaga, A.S., Elhardlu, H.I. and Elmusharaf, K. (2016) Renal Manifestations among Adult Sickle Cell Disease Patients: A Single Center Study in Khartoum, Sudan. Open Journal of Nephrology, 6, 157-160.

http://dx.doi.org/10.4236/ojneph.2016.64020

Received: November 1, 2016

Accepted: December 16, 2016

Published: December 19, 2016

Copyright (c) 2016 by authors and Scientific Research Publishing Inc. This work is licensed under the Creative Commons Attribution International License (CC BY 4.0).

http://creativecommons.org/licenses/by/4.0/

\begin{abstract}
Sickle Cell Disease (SCD) in adults is one of the causes of renal abnormalities and Chronic Kidney Disease (CKD). In this retrospective study, we explore the renal manifestations among adult SCD patients. The subjects of the study are all adult patients diagnosed with sickle cell anaemia and admitted as to the Academy Charity Teaching Hospital, Khartoum/Sudan during the period (01/01/2015-31/12/2015). All adult SCD patients' medical files have been reviewed focusing on personal and clinical data in addition to presence or absence of renal manifestations, a total of 51 adult patients with SCD have been admitted to Academy Charity Teaching Hospital, Khartoum/ Sudan. 11 patients have renal manifestations (21.5\%). The mean age \pm SD of SCD patients with renal manifestations was $20.2 \pm 1.9$ years, $63.6 \%$ were males, the mean $\mathrm{Hb}$ level was $6.9 \pm 0.99 \mathrm{gm} / \mathrm{dl}$, proteinuria was present among $81.8 \%$ of patients, followed by haematuria (36.4\%) and End Stage Renal Failure (ESRF) (18.2\%). Further prospective studies are needed to explore the renal abnormalities among adult SCD patients.
\end{abstract}

\section{Keywords}

Sickle Cell Disease, Renal Manifestations, Sudan

\section{Introduction}

Sickle Cell Disease (SCD) is a hereditary hematological disorder resulting from the presence of mutated form of hemoglobin, hemoglobin S (HbS) [1]. The prevalence of 
renal involvement in SCD ranges from 5 to 18\% [2]. 1.3\% of causes of End Stage Renal Failure (ESRF) among patients less than 40 years old on regular haemodialysis in Khartoum/Sudan were due to SCD [3]. Sickle cell anaemia is associated with renal ischemia, glomerular diseases and nephrotic syndrome [4] [5]. 40\% of causes of mortality among adult SCD patients were due to renal failure [6]. Several published studies identified microalbuminuria and proteinuria as major renal manifestations among adult SCD patients [7] [8]. In this study, we focused on renal manifestations of adult Sudanese patients with SCD.

\section{Materials and Methods}

This is a hospital based cross sectional descriptive study. Medical records of all patients diagnosed and admitted as sickle cell anaemia to the Academy Charity Teaching Hospital, Khartoum/Sudan during the period (01/01/2015 - 31/12/2015) were reviewed retrospectively, We collected socio demographics characteristics of the patients, clinical data, and presence or absence of renal manifestations, we included all patients diagnosed as sickle cell anaemia admitted to the Academy Charity Teaching Hospital, Khartoum/Sudan during the study period, we excluded patients less than 18 years old. The research was approved by Ethics and Research Comities in the Ministry of Health and the local hospital.

\section{Results}

A total of 51 adult patients with SCD have been admitted to the hospital during the study period. 11 patients have renal manifestations (21.5\%). The mean age of SCD patients with renal manifestations was $20.2 \pm 1.9$ years, $63.6 \%$ were males. The mean $\mathrm{Hb}$

Table 1. Characteristics of the study population $(n=11)$.

\begin{tabular}{cc}
\hline Age $^{1}$ & $20.2 \pm 1.9$ years \\
\hline Gender $^{2}$ & Male: $7(63.6 \%)$ \\
& Female: $4(36.4 \%)$ \\
Clinical presentation & \\
& Acute Chest Syndrome: $3(27.2 \%)$ \\
& Abdominal Crisis: $3(27.2 \%)$ \\
Hb level & Hemolytic Crisis: $5(45.4 \%)$ \\
& Anaemia needed blood transfusion: $6(54.5 \%)$ \\
\end{tabular}

${ }^{1}$ Mean $\pm \mathrm{SD} ;{ }^{2}$ Number (percentage).

Table 2. Renal manifestation of patients with sickle cell anaemia $(n=11)$.

\begin{tabular}{cc}
\hline Renal Manifestations & Frequency \\
\hline Proteinuria & $9(81.8 \%)$ \\
Nephrotic syndrome & $4(36.4 \%)$ \\
Haematuria & $4(36.4 \%)$ \\
End Stage Renal failure & $2(18.2 \%)$ \\
\hline
\end{tabular}


level was $6.9 \pm 0.99 \mathrm{gm} / \mathrm{dl}$. Five patients $(45.5 \%)$ were presented with hemolytic crisis and six patients (54.5\%) were needed blood transfusion (Table 1). Proteinuria was present among nine patients (81.8\%), followed by haematuria in four patients $(36.4 \%)$ and ESRF in two patients (18.2\%) (Table 2).

\section{Discussion}

In this study we found that $21.5 \%$ of adult SCD patients have renal manifestations. In published literature, prevalence of renal involvement in SCD range from 5 to $18 \%$ [2]. In this study, proteinuria was the major renal manifestation among adult SCD patients. Several published studies identified microalbuminuria and proteinuria as major renal manifestations among adult SCD patients. In one study a urinary screening of asymptomatic SCD patients revealed microalbuminuria in $15.8 \%$ of patients [7]. Another study indicated that $22.3 \%$ of SCD patients had microalbuminuria [8]. Further studies pointed out that prevalence of proteinuria among adult SCD patients range between $26 \%$ and $68 \%$ [9]. Broad ranges of glomerular lesion were detected among SCD adults' patients. Focal Segmental Glomerulosclerosis (FSGS) and Membranoproliferative Glomerulonephritis (MPGN) were the most common glomerular lesions among adult SCD patients [10] [11].

In this study $36.4 \%$ of SCD patients with renal manifestations have haematuria. Previous studies indicated that the prevalence of haematuria among SCD patients ranged between $8.5 \%$ and $30 \%$ [12] [13]. Haematuria usually resulted from sickling of red blood cells in renal medulla. However, haematuria can occur as a consequence of acute papillary necrosis or renal medullary carcinoma [14].

In this study $18.2 \%$ of adult SCD patients with renal manifestations have renal dysfunction and ESRF. Patients with sickle cell anaemia have increased risk of development of CKD. $40 \%$ of causes of mortality among adult SCD patients were due to renal failure [6]. Factors determining the development of CKD among adult SCD patients were presence of proteinuria, hypertension and acute renal failure [15].

There were limitations in our study. It was a retrospective review of the medical records. This prevented us from exploring more details on other renal manifestations of SCD that may be present in our patient.

\section{Conclusion}

In conclusion, the current study found that $21.5 \%$ of adult SCD patients had renal manifestations. Proteinuria was the major renal manifestation among our patients followed by haematuria and renal dysfunction.

\section{References}

[1] Strouse, J. (2016) Sickle Cell Disease. Handbook of Clinical Neurology, 138, 311-324. https://doi.org/10.1016/B978-0-12-802973-2.00018-5

[2] Scheinman, J.I. (1994) Sickle Cell Nephropathy. In: Holliday, M., Barratt, T.M. and Avner, E.D., Eds., Pediatric Nephrology, Williams \& Wilkins, Baltimore, 908-919. 
[3] Banaga, A.S., Mohammed, E.B., Siddig, R.M., Salama, D.E., Elbashir, S.B., Khojali, M.O., Babiker, R.A., Elmusharaf, K. and Homeida, M.M. (2015) Causes of End Stage Renal Failure among Haemodialysis Patients in Khartoum State/Sudan. BMC Research Notes, 8, 502. https://doi.org/10.1186/s13104-015-1509-x

[4] Ataga, K.I., Derebail, V.K. andArcher, D.R. (2014) The Glomerulopathy of Sickle Cell Disease. American Journal of Hematology, 89, 907-914. https://doi.org/10.1002/ajh.23762

[5] Powars, D.R., Elliott-Mills, D.D., Chan, L., Niland, J., Hiti, A.L., Opas, L.M. and Johnson, C. (1991) Chronic Renal Failure in Sickle Cell Disease: Risk Factors, Clinical Course, and Mortality. Annals of Internal Medicine, 115, 614-620.

[6] Platt, O.S., Brambilla, D.J., Rosse, W.F., Milner, P.F., Castro, O., Steinberg, M.H. and Klug, P.P. (1994) Mortality in Sickle Cell Disease. Life Expectancy and Risk Factors for Early Death. The New England Journal of Medicine, 330, 1639-1644. https://doi.org/10.1056/NEJM199406093302303

[7] Alvarez, O., Montane, B., Lopez, G., Wilkinson, J. and Miller, T. (2006) Early Blood Transfusions Protect against Microalbuminuria in Children with Sickle Cell Disease. Pediatric Blood \& Cancer, 47, 71-76. https://doi.org/10.1002/pbc.20645

[8] Iwalokun, B.A., Iwalokun, S.O., Hodonu, S.O., Aina, O.A. and Agomo, P.U. (2012) Evaluation of Microalbuminuria in Relation to Asymptomatic Bacteruria in Nigerian Patients with Sickle Cell Anemia. Saudi Journal of Kidney Diseases and Transplantation, 23, 1320-1330.

[9] Falk, R.J., Scheinman, J., Phillips, G., Orringer, E., Johnson, A. and Jennette, J.C. (1992) Prevalence and Pathologic Features of Sickle Cell Nephropathy and Response to Inhibition of Angiotensin-Converting Enzyme. The New England Journal of Medicine, 326, 910-915. https://doi.org/10.1056/NEJM199204023261402

[10] Bhathena, D.B. and Sondheimer, J.H. (1991) The Glomerulopathy of Homozygous Sickle Hemoglobin (SS) Disease: Morphology and Pathogenesis. Journal of the American Society of Nephrology, 1, 1241-1252.

[11] Maigne, G., Ferlicot, S., Galacteros, F., Belenfant, X., Ulinski, T., Niaudet, P., Ronco, P., Godeau, B., Durrbach, A., Sahali, S., et al. (2010) Glomerular Lesions in Patients with Sickle Cell Disease. Medicine, 89, 18-27. https://doi.org/10.1097/MD.0b013e3181ca59b6

[12] Aleem, A. (2008) Renal Abnormalities in Patients with Sickle Cell Disease: A Single Center Report from Saudi Arabia. Saudi Journal of Kidney Diseases and Transplantation, 19, 194199.

[13] Sesso, R., Almeida, M.A., Figueiredo, M.S. and Bordin, J.O. (1998) Renal Dysfunction in Patients with Sickle Cell Anemia or Sickle Cell Trait. Brazilian Journal of Medical and Biological Research, 31, 1257-1262. https://doi.org/10.1590/S0100-879X1998001000004

[14] Alhwiesh, A. (2014) An Update on Sickle Cell Nephropathy. Saudi Journal of Kidney Diseases and Transplantation, 25, 249-265. https://doi.org/10.4103/1319-2442.128495

[15] Yeruva, S.L., Paul, Y., Oneal, P. and Nouraie, M. (2016) Renal Failure in Sickle Cell Disease: Prevalence, Predictors of Disease, Mortality and Effect on Length of Hospital Stay. Hemoglobin, 40, No. 5. https://doi.org/10.1080/03630269.2016.1224766 
Submit or recommend next manuscript to SCIRP and we will provide best service for you:

Accepting pre-submission inquiries through Email, Facebook, LinkedIn, Twitter, etc. A wide selection of journals (inclusive of 9 subjects, more than 200 journals)

Providing 24-hour high-quality service

User-friendly online submission system

Fair and swift peer-review system

Efficient typesetting and proofreading procedure

Display of the result of downloads and visits, as well as the number of cited articles

Maximum dissemination of your research work

Submit your manuscript at: http://papersubmission.scirp.org/

Or contact ojneph@scirp.org 